Funny Pictures 
The publisher gratefully acknowledges the generous support of the Ahmanson Foundation Humanities Endowment Fund of the University of California Press Foundation. 


\section{Funny Pictures}

Animation and Comedy
in Studio-Era Hollywood

Edited by

Daniel Goldmark and Charlie Keil

届

UNIVERSITY OF CALIFORNIA PRESS

Berkeley Los Angeles London 
University of California Press, one of the most distinguished university presses in the United States, enriches lives around the world by advancing scholarship in the humanities, social sciences, and natural sciences. Its activities are supported by the UC Press Foundation and by philanthropic contributions from individuals and institutions. For more information, visit www.ucpress.edu.

University of California Press

Berkeley and Los Angeles, California

University of California Press, Ltd.

London, England

(C) 2011 by The Regents of the University of California

Library of Congress Cataloging-in-Publication Data

Funny pictures : animation and comedy in studio-era Hollywood / edited by Daniel Goldmark and Charlie Keil.

p. $\mathrm{cm}$.

Includes bibliographical references and index.

ISBN 978-0-520-26723-7 (cloth : acid-free paper)

ISBN 978-0-520-26724-4 (pbk. : acid-free paper)

1. Animated films-United States-History and criticism. 2. Wit and humor in motion pictures. I. Goldmark, Daniel. II. Keil, Charlie.

NC1766.U5F86 2011

$791.43340973-\mathrm{dc} 22$

2011005494

Manufactured in the United States of America

$\begin{array}{lllllllll}19 & 18 & 17 & 16 & 15 & 14 & 13 & 12 & 11\end{array}$

$\begin{array}{llllllllll}10 & 9 & 8 & 7 & 6 & 5 & 4 & 3 & 2 & 1\end{array}$

In keeping with a commitment to support environmentally responsible and sustainable printing practices, UC Press has printed this book on Cascades Enviro 100, a 100 percent postconsumer waste, recycled, de-inked fiber. FSC recycled certified and processed chlorine free. It is acid free, Ecologo certified, and manufactured by BioGas energy. 